\title{
Suramin Interferes with Interleukin-6 Receptor Binding In Vitro and Inhibits Colon-26-mediated Experimental Cancer Cachexia In Vivo
}

Gideon Strassmann, * Miranda Fong, * Carl E. Freter, ${ }^{*}$ Sandra Windsor, * Francesco D'Alessandro, ${ }^{*}$ and Richard P. Nordan

${ }^{*}$ Department of Immunology, Otsuka America Pharmaceutical, Inc., Rockville, Maryland 20850; ${ }^{\ddagger}$ Clinical Pharmacology Branch, National Cancer Institute, National Institutes of Health, Bethesda, Maryland 20852; and ${ }^{\S}$ Division of Medical Oncology,

Georgetown University Medical Center, Washington, D.C. 20007

\begin{abstract}
Neoplastic diseases are frequently associated with metabolic changes collectively known as cancer cachexia. The presence of cachexia complicates therapeutic intervention and is an important cause of death in cancer patients. At present there is no effective treatment for cachexia. Recently, the involvement of interleukin-6 (IL-6) in the wasting of colon-26 adenocarcinoma-bearing mice was demonstrated. The research presented here establishes an anticachectic role for the experimental drug suramin, since it partially blocks (up to $60 \%$ ) the catabolic effects associated with the growth of this tumor in vivo. Suramin prevents the binding of IL-6 to its cell surface receptor subunits, as demonstrated by radioreceptor binding assay and affinity crosslinking experiments. Furthermore, the uptake of radioactive IL-6 by the liver is significantly reduced in suramintreated mice. On the other hand, the drug is $\sim 10$-fold less potent in inhibiting the binding of tumor necrosis factor- $\alpha$ to indicator cell line in vitro and fails to block liver uptake of this cytokine in vivo. Collectively, these results suggest that suramin inhibits cancer-associated wasting, in part by interfering with the binding of IL-6 to its receptor. Whether suramin inhibits the action of other factors / cytokines that may also participate in colon-26-mediated cachexia is not yet known. ( J. Clin. Invest. 1993. 92:2152-2159.) Key words: cancer cachexia • IL$6 \cdot$ IL-6 receptor $\cdot$ suramin $\cdot$ colon-26 tumor
\end{abstract}

\section{Introduction}

Weight loss is a common manifestation of many chronic illnesses, including cancer, and bacterial, viral, and parasitic infections (1). In humans, neoplastic diseases are frequently associated with a constellation of metabolic changes collectively known as "cancer cachexia" $(2,3)$. Among these changes are progressive wasting of both muscle and fat tissues, anemia, anorexia, and asthenia. Cachexia long has been recognized as an important cause of death in cancer patients (4), and patients who exhibit cachexia have a reduced response to chemotherapy (5). Wasting is common in cancer patients. Up to $50 \%$ of all patients have lost weight by the time of diagnosis, and nearly all patients who die from cancer exhibit wasting (6). Recent attempts to compensate, through total parenteral nutrition, for the negative caloric balance in patients failed to alter

Address correspondence to Dr. Gideon Strassmann, Department of Immunology, Otsuka America Pharmaceutical, Inc. 9900 Medical Center Drive, Rockville, MD 20850.

Received for publication 2 December 1992 and in revised form 7 May 1993.

The Journal of Clinical Investigation, Inc.

Volume 92, November 1993, 2152-2159 wasting (7). The mitigation of wasting by pharmacological intervention, therefore, is important not only because anticachexia therapy could improve the survival and quality of life of the patient, but also because it could give way to a more effective anticancer therapy.

Cachectin/TNF has been suggested as an important mediator of cancer cachexia because it suppresses key metabolic enzymes and induces anorexia and weight loss in animals (1, 8-10). Recently, however, an experimental cachexia model has been identified that appears to involve another cytokine. The model uses a cell line derived from colon-26 adenocarcinoma (C-26), ${ }^{1}$ which retains the transplantability of the original tumor in syngeneic mice and fulfills the criteria of early-onset wasting without apparent anorexia (11). In at least this model, IL-6 appears to have a more significant role than TNF in mediating the myriad parameters of cachexia (11). The cellular source of IL- 6 in this model is believed to be derived from the tumor cells, in response to IL-1 provided by tumor-infiltrating mononuclear phagocytes (12).

The experimental drug suramin (a polysulfated naphthylurea) was originally developed as an antitrypanosomal and antifilarial agent (13). Recently suramin was found to inhibit the growth of several tumor cell lines in culture $(14,15)$, and to inhibit the enzyme reverse transcriptase (16). Previous work suggested that suramin blocks the activity of IL-6 as an autocrine/paracrine growth factor in human multiple myeloma cell lines $(17,18)$. Suramin can also induce cell differentiation in several systems (19), suppress tumor cell invasion (20), and inhibit the nuclear enzyme DNA topoisomerase II (21). Therefore, suramin is currently being investigated in the clinic for the treatment of AIDS (22) and several inoperable cancers (23, $24)$. In culture, suramin is known to block binding of various growth factors (among them EGF, IGF-1, TGF- $\beta$, PDGF, and basic fibroblast growth factor) to their corresponding cell surface receptors (25-29). In this report, we demonstrate that suramin interferes with the binding of IL- 6 to its cell surface receptor, and significantly inhibits the catabolism of C-26bearing hosts.

\section{Methods}

Cell culture. Cell culture was performed in complete medium, which consisted of either RPMI 1640 or DME (Gibco Laboratories, Grand Island, NY) supplemented with $10 \%$ FCS (Whittaker Bioproducts, Walkersville, MD) and antibiotics, at $37^{\circ} \mathrm{C}$ in a humidified atmosphere of $5 \% \mathrm{CO}_{2}$. U-266, a human myeloma cell line, and MCF-7, a human breast tumor line, were obtained from the American Type Culture Collection (Rockville, MD). The IL-6-dependent murine cell line B-9 was grown in complete RPMI supplemented with $50 \mu \mathrm{M} 2$-mercaptoethanol and recombinant IL-6.

1. Abbreviation used in this paper: C-26, colon-26 adenocarcinoma. 
Mice. Virus-free, male BALB/c $\times$ DBA/2 $(\mathrm{CD}) \mathrm{F}_{1}$ mice were purchased from Charles River Breeding Laboratories (Wilmington, MA). Mice were housed under conventional conditions and were used at 8-14 wk of age.

Radioactive IL-6. Human ${ }^{125} \mathrm{I}-\mathrm{IL}-6$ (sp act, $2,000 \mathrm{Ci} / \mathrm{mmol}$ ) was purchased from Amersham Corp. (Arlington Heights, IL) or was labeled by us. Briefly, IL-6 (R \& D Systems, Minneapolis, MN) was labeled using the diiodo ${ }^{125} \mathrm{I}$-Bolton-Hunter reagent $(2,200 \mathrm{Ci} / \mathrm{mmol}$; DuPont/NEN, Boston, MA) as previously described (30). The specific activity of the ${ }^{125}$ I-IL-6 was calculated to be $2-4 \times 10^{15} \mathrm{cpm} /$ mmol. More than $99 \%$ of the radioactivity corresponded to a single band of IL- 6 when analyzed under both reducing and nonreducing SDS-PAGE, and autoradiography. Human ${ }^{125} \mathrm{I}-\mathrm{TNF} \alpha$ (sp act, $520 \mathrm{Ci}$ / $\mathrm{mmol}$ ) was purchased from New England Nuclear (Boston, MA). The biologic activity of the radioactive IL- 6 was found to be essentially unchanged as measured using the IL-6-dependent B-9 cell line.

Affinity crosslinking of ${ }^{125} \mathrm{I}-\mathrm{IL}-6$ to its receptor. Affinity crosslinking was performed using a modification of a previously published procedure (31). Briefly, cells were washed twice and resuspended at $5 \times 10^{7}$ cells $/ \mathrm{ml}$ in cold binding medium ( $\mathrm{RPMI} 1640,0.05 \%$ sodium azide). Binding was allowed to proceed on ice for the indicated time with the indicated amount of ${ }^{125} \mathrm{I}-\mathrm{IL}-6$. After binding, the cells were washed with cold RPMI 1640/0.05\% sodium azide to remove the unbound ${ }^{125}$ I-IL-6 and resuspended in $1 \mathrm{ml}$ of PBS, $1 \mathrm{mM} \mathrm{MgCl}$, $\mathrm{pH}$ 8.3. Crosslinking was initiated by the addition of $300 \mu \mathrm{g} / \mathrm{ml}$ disuccinimidyl suberate (Pierce Chemical Co., Rockford, IL), as indicated, and allowed to proceed at $4^{\circ} \mathrm{C}$ for $15 \mathrm{~min}$. The crosslinking reaction was stopped by centrifugation and by immediate lysis of the cells with $50 \mathrm{mM}$ Tris- $\mathrm{HCl}$, $300 \mathrm{mM} \mathrm{NaCl}, 1 \% \mathrm{NP}-40,1 \mathrm{mM}$ PMSF, $10 \mathrm{mM}$ leupeptin, and 10 $\mathrm{mM}$ pepstatin, $\mathrm{pH} 7.5$ (lysis buffer), for $30 \mathrm{~min}$ on ice. The lysate was centrifuged for $10 \mathrm{~min}$ at $15,000 \mathrm{~g}$ and the supernatant collected for analysis by SDS-PAGE and autoradiography.

Binding assays. This assay was performed as described previously (32). U-266 cells were grown to confluence, medium was removed, and the cells were washed in binding buffer (RPMI 1640 supplemented with $0.1 \mathrm{mg} / \mathrm{ml} \mathrm{BSA}$ and $25 \mathrm{mM}$ Hepes, $\mathrm{pH} 7.2$ ), and 0.05-ml aliquots of $10 \times 10^{6}$ cells $/ \mathrm{ml}$ were dispensed into tubes on ice. Increasing amounts of suramin and $0.8 \mathrm{ng}$ of ${ }^{125}$ I-IL- 6 were added simultaneously at the indicated concentrations. The cells were incubated for $90 \mathrm{~min}$ at $4^{\circ} \mathrm{C}$ with gentle agitation. To separate cells bound from free ${ }^{125} \mathrm{I}-\mathrm{IL}-6$, $0.2 \mathrm{ml}$ of an oil mixture was injected into the bottom of the tubes, which were centrifuged for $1 \mathrm{~min}$. The fluid was aspirated, the tube tips were cut, and cell-bound radioactivity was determined in a gamma counter. Binding of ${ }^{125} \mathrm{I}-\mathrm{TNF} \alpha(1.0 \mathrm{ng})$ was performed on confluent monolayers of MCF-7 cells with the same binding buffer. Cells were then washed three times with cold binding buffer, trypsinized, and cell-bound radioactivity was measured.

IL-6 bioassay and ELISA. This assay was previously described (32). Briefly, B-9 cells were grown in human IL-6. To measure IL-6 activity in serum or inhibition by suramin, IL-6-dependent B-9 cells ( 5 $\times 10^{3} /$ well ) were cultured at a final volume of $0.2 \mathrm{ml}$ with or without diluted samples in flat-bottomed 96-well plates (Falcon Labware, Oxnard, CA ). After incubation for $72 \mathrm{~h}$, cells were pulsed for the final $4 \mathrm{~h}$ with $1 \mu \mathrm{Ci} /$ well of $\left[{ }^{3} \mathrm{H}\right]$ thymidine. Incorporation of radioactivity was determined by standard liquid scintillation counting procedures after collection of cells on glass fiber paper. Results are expressed in units where $1 \mathrm{U}$ was defined as the reciprocal dilution required for half-maximal stimulation of the cells. IL- 6 was also quantified by a murine-specific IL-6 ELISA (Endogen, Boston, MA).

Measurement of cachexia markers. Mice were inoculated with 0.5 $\times 10^{6} \mathrm{C}-26 . \mathrm{IVX}$ cells subcutaneously to the right flank as described $(11,12)$. Treatments were performed as indicated in the tables. Mice were weighed between 9 and 11 a.m. several times per week. The length and width of their tumors were measured using an engineering caliper, and estimation of tumor weight was calculated, as previously described, for the same tumor (33). Significant weight loss in C-26-bearing mice occurred between 12 and $14 \mathrm{~d}$ after tumor inoculation. Host weight was calculated by subtracting tumor weight (obtained by resection) from total weight. Blood was obtained by cardiac puncture $(\sim 0.8 \mathrm{ml})$, and serum was harvested after the clotting of blood at room temperature for $1 \mathrm{~h}$. Serum was kept frozen $\left(-45^{\circ} \mathrm{C}\right)$ until analysis. Measurements of serum glucose were performed using an Ektachem DT-60 analyzer (Eastman Kodak Co., Rochester, NY). Dry weight was determined (after removal of the tumor, blood, and right epididymal fat pad) by oven drying for $3 \mathrm{~d}$ at $85^{\circ} \mathrm{C}$. The neutralizing mAb against murine IL-6 20F3 was the gift of Dr. C. O. Jacob (Syntex Research, Palo Alto, CA) (11).

Statistical analysis. Results throughout the paper are presented as mean $\pm S D$. Differences in cachexia markers were calculated using computerized analysis of variance (ANOVA).

\section{Results}

Inhibition of IL-6 activities by suramin in vitro. The addition of suramin to the B-9 murine myeloma line inhibits the proliferation of these cells in response to IL-6. Half-maximal inhibition of thymidine incorporation was seen at $\sim 30 \mu \mathrm{M}$ of the drug when various doses $(3-30 \mathrm{pg} / \mathrm{ml})$ of recombinant human $(\mathrm{rh})$ IL-6 were added to the culture (Table I). In contrast, 10-fold more drug was required to achieve the same extent of inhibition when B-9 cells were incubated with $1 \mathrm{ng} / \mathrm{ml}$ of IL-6 (not shown). The inhibition was not specific to IL-6, since the drug also inhibited B-9 proliferation in response to increasing concentrations of IL-4. When B-9 cells were pretreated with suramin, up to $1 \mathrm{mM}$ for $1 \mathrm{~h}$ at room temperature, followed by

Table I. Suramin Inhibits B-9 Cell Proliferation in Response to IL-6 and IL-4

\begin{tabular}{|c|c|c|c|c|c|c|}
\hline \multirow[b]{2}{*}{ Cytokine } & \multicolumn{3}{|c|}{ IL-6 (pg/ml) } & \multicolumn{3}{|c|}{ IL-4 (U/ml) } \\
\hline & 30 & 10 & 3 & 100 & 30 & 10 \\
\hline $\begin{array}{l}\text { No compound } \\
\text { Suramin }(\mu \mathrm{M})\end{array}$ & 252,895 & 144,526 & 29,728 & 175,269 & 138,423 & 65,445 \\
\hline 300 & 5,654 & 1,811 & 1,105 & 3,448 & 2,288 & 1,106 \\
\hline 100 & 59,444 & 9,339 & 2,389 & 23,422 & 6,363 & 1,536 \\
\hline 30 & 229,221 & 81,766 & 11,989 & 103,774 & 70,344 & 23,354 \\
\hline 10 & 265,263 & 139,000 & 32,726 & 162,384 & 150,385 & 74,314 \\
\hline 3 & 233,260 & 156,001 & 32,537 & 159,604 & 139,569 & 81,819 \\
\hline
\end{tabular}

Results are expressed as cpm of $\left[{ }^{3} \mathrm{H}\right]$ thymidine incorporation to B-9 cells. Standard deviation did not exceed $10 \%$. Background proliferation in the assay was $2,301 \mathrm{cpm}$. The experiment was repeated five times with similar results. 
washing of the cells, no inhibition of cell proliferation occurred (data not shown).

Because suramin is known to prevent binding of various growth factors to their cell surface receptors (25-28), it was of interest to determine whether the inhibition of B-9 cell growth was possibly due to the prevention of IL- 6 binding to its receptor. To this end, the U-266 human myeloma line, which expresses a relatively high number of IL- 6 receptors, was used in standard IL- 6 receptor binding assays. At $4^{\circ} \mathrm{C}$, suramin inhibited the binding of ${ }^{125}$ I-IL-6 to U-266 cells (Fig. 1). In this representative experiment, the extent of inhibition of cell-associated radioactivity reached almost $100 \%$. The determination of background binding involved the addition of 625 -fold excess of cold IL-6. This experiment was highly reproducible, since more than eight experiments in two separate laboratories with different batches of radioactive IL- 6 showed similar results. Half-maximal inhibition in these experiments was achieved at $\sim 30 \mu \mathrm{M}$ of the drug. On the other hand, suramin was not as effective in inhibiting the binding of ${ }^{125}$ I-TNF $\alpha$ to the MCF-7 cell line. Half-maximal inhibition of TNF $\alpha$ binding was achieved at only $\sim 300 \mu \mathrm{M}$ of the drug (Fig. 1). To analyze still further the inhibitory effect of suramin on IL-6 binding, affinity crosslinking experiments were performed. Crosslinking membrane-bound ${ }^{125}$ I-IL-6 to U-266 cells generates three IL-6containing crosslinked complexes with molecular masses of 100,120 , and $150 \mathrm{kD}$. As shown in Fig. 2, suramin concentrations as low as $25 \mu \mathrm{M}$ display inhibition of complex formation whereas concentrations $\geq 100 \mu \mathrm{M}$ completely block the formation of all three IL-6/IL-6 receptor complexes. To better understand this effect, we asked if suramin could dissociate bound IL- 6 from the receptor complex. Fig. 3 demonstrates that concentrations of suramin that inhibit the formation of IL-6/IL-6 receptor complexes are unable to dissociate bound IL-6 from the receptor complex. In addition, radioreceptor binding assays confirmed the results presented in Fig. 3. At $4^{\circ} \mathrm{C}$, suramin did not displace prebound radioactive IL-6 on U-266 cells ( not shown).

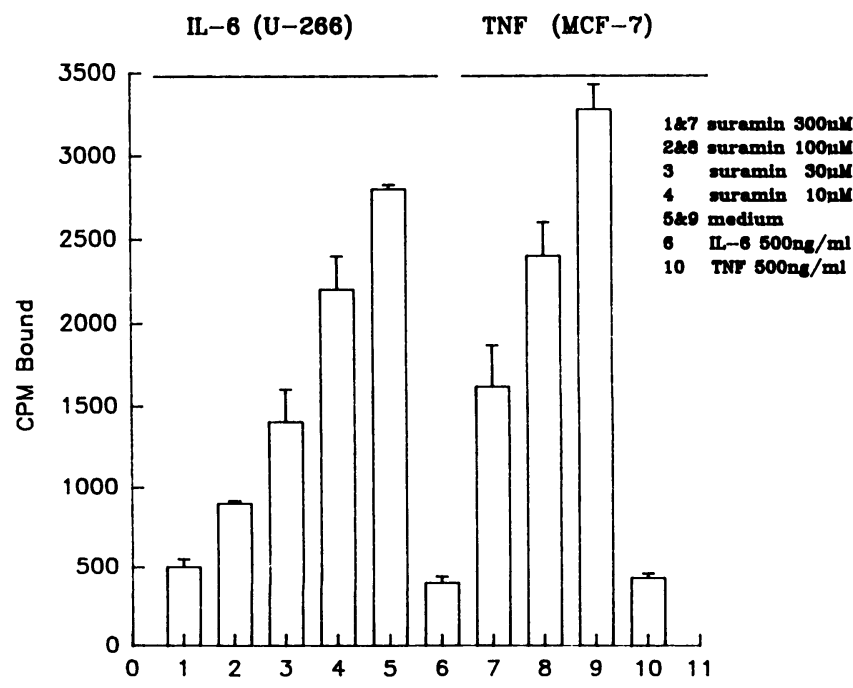

Figure 1. Inhibition of binding of IL- 6 and TNF $\alpha$ to indicator cells by suramin. $5 \times 10^{5} \mathrm{U}-266$ or MCF-7 cells were incubated with a saturating amount of ${ }^{125} \mathrm{I}-\mathrm{IL}-6$ and ${ }^{125} \mathrm{I}-\mathrm{TNF} \alpha$, respectively, and increasing amounts of suramin ( right) for $90 \mathrm{~min}$ at $4^{\circ} \mathrm{C}$. Cell-associated radioactivity was determined as described in Methods.

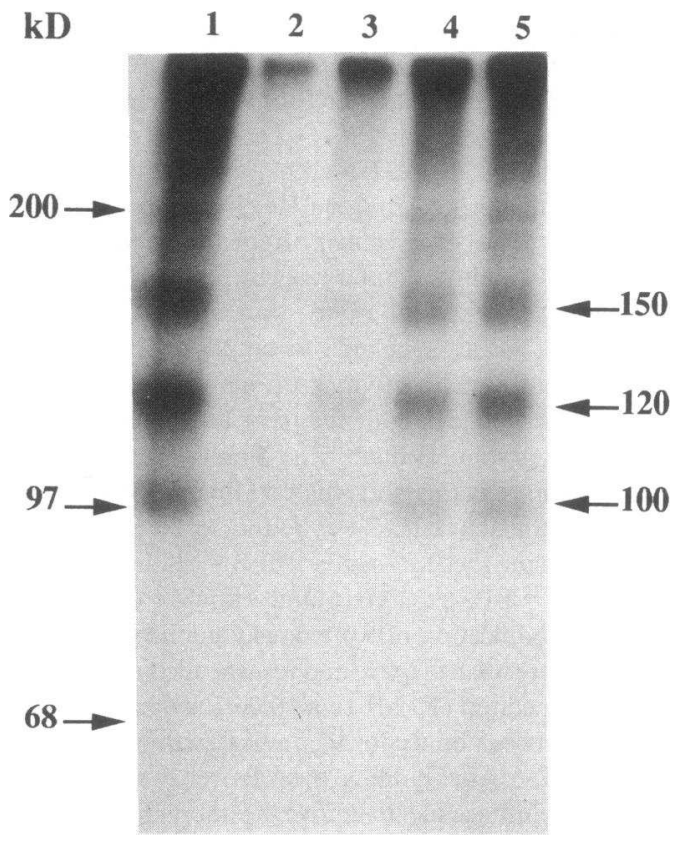

Figure 2. Effect of suramin on the formation of IL-6/IL-6 receptor complexes. $4 \times 10^{6} \mathrm{U}-266$ cells were incubated at $4^{\circ} \mathrm{C}$ for $2 \mathrm{~h}$ with $5 \mathrm{nM}^{125} \mathrm{I}-\mathrm{IL}-6$ plus various concentrations of suramin as described in Methods. After removal of suramin and unbound ligand, the cells were crosslinked with disuccinimidyl suberate for $15 \mathrm{~min}$ at $4^{\circ} \mathrm{C}$, lysed, and analyzed by reducing SDS-PAGE and autoradiography. Lane 1, no suramin; lane 2, $200 \mu \mathrm{M}$ suramin; lane 3, $100 \mu \mathrm{M}$ suramin; lane 4, $50 \mu \mathrm{M}$ suramin; lane 5, $25 \mu \mathrm{M}$ suramin.

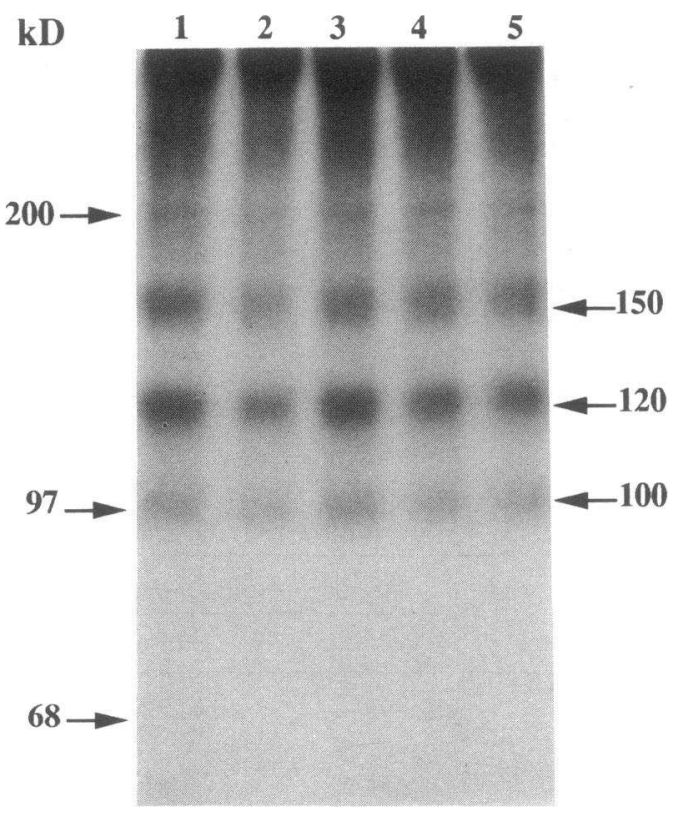

Figure 3. Effect of suramin on prebound IL-6/IL-6 receptor complexes. $4 \times 10^{6} \mathrm{U}-266$ cells were incubated at $4^{\circ} \mathrm{C}$ for $1 \mathrm{~h}$ with $5 \mathrm{nM}$ ${ }^{125} \mathrm{I}-\mathrm{IL}-6$. After removal of unbound ligand, the cells were incubated with various concentrations of suramin for $1 \mathrm{~h}$ at $4^{\circ} \mathrm{C}$. After removal of suramin, the cells were crosslinked and processed as described in Fig. 2. Lane 1, no suramin; lane 2, $200 \mu \mathrm{M}$ suramin; lane 3, $100 \mu \mathrm{M}$ suramin; lane 4, $50 \mu \mathrm{M}$ suramin; lane 5, $25 \mu \mathrm{M}$ suramin. 

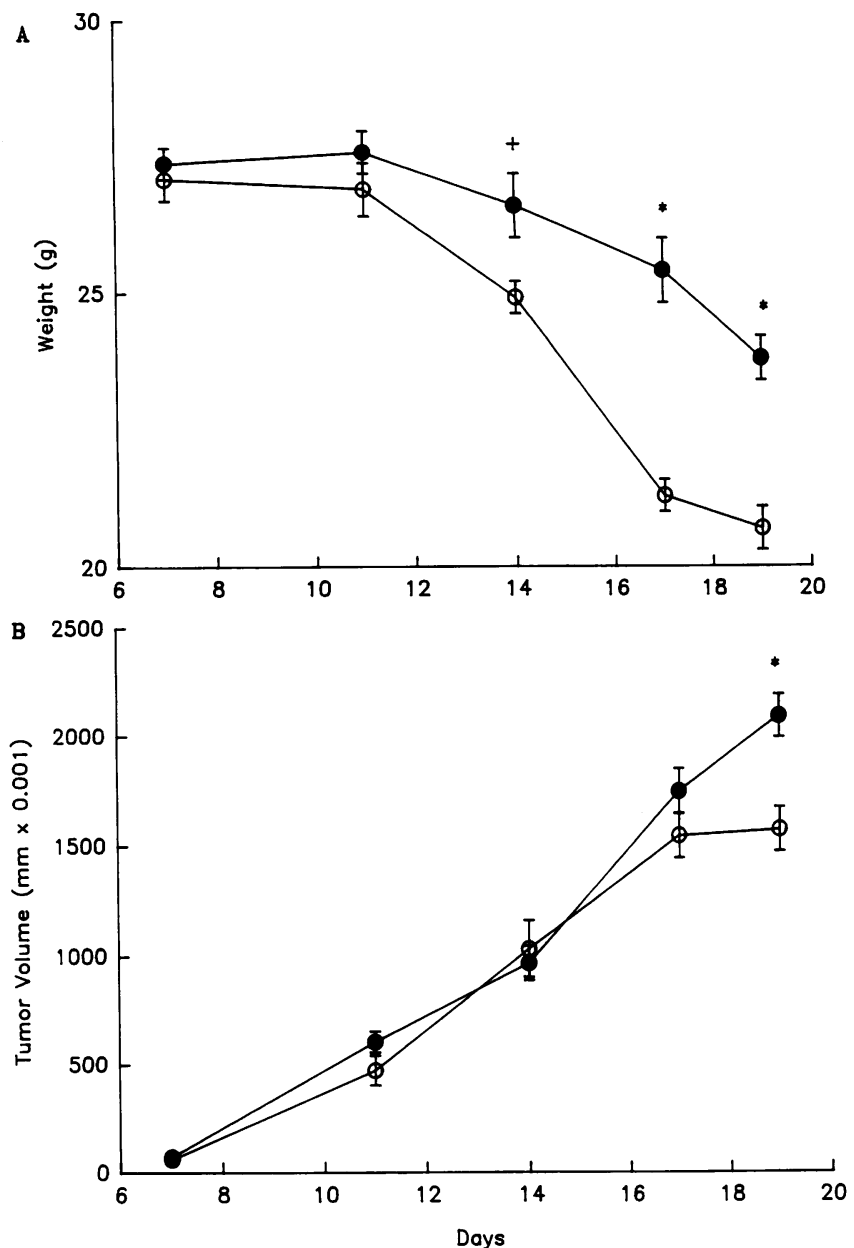

Figure 4. Inhibition of C-26-mediated wasting by suramin. Mice were inoculated with $5 \times 10^{5} \mathrm{C}-26$. IVX cells on day 0 . The weight $(A)$ and tumor size $(B)$ were determined as described in Methods. Filled circles represent eight mice receiving $100 \mathrm{mg} / \mathrm{kg}$ i.p. of suramin on days 7 and 12, while open circles represent eight mice injected with PBS on the same days. ${ }^{*} P<0.002 ;{ }^{+} P<0.002$.
Suramin inhibits C-26-mediated wasting. The administration of suramin to C-26.IVX-bearing mice on days 7 and 12 significantly improved the total weight (host and tumor) of these animals as compared with PBS-injected controls (Fig. 4 $A$ ). The measurements of tumor volume in the experiment revealed that, on days 14 and 17 of posttumor inoculation, the suramin-treated hosts were significantly protected from wasting, since they exhibited an identical tumor burden to controltreated hosts (Fig. $4 B$ ). On day 19, suramin-treated animals showed a statistically larger tumor burden. However, for unknown reasons, this augmentation in tumor burden did not occur in all the experiments (for example, see Table II). Of note, non-tumor-bearing mice treated with the drug exhibited weights that were indistinguishable from that of PBS-treated age-matched normal animals (not shown). The beneficial effect of suramin in inhibiting C-26-mediated weight loss required a dose of $\sim 75 \mathrm{mg} / \mathrm{kg}$, administered twice on days 7 and 12 posttumor inoculation (Fig. 5). Body compositional analyses of C-26-bearing mice confirmed the protective effect of suramin. Table II depicts three separate experiments where different protocols of suramin treatment and termination days were used. Significant improvements in cachexia markers, including host weight, dry weight, heart weight, epididymal fat weight, and hypoglycemia, could be seen in suramin-treated mice. Of note, irrespective of the tumor burden, serum IL-6 levels in suramin-treated mice tended to be higher than in PBStreated C-26-bearing mice. Quantification of serum samples using a murine ELISA showed a close correlation with the results obtained in the B-9 assay (data not shown). Thus, the data appear to suggest that the increase in IL-6 in the serum of suramin-treated mice might be due to interference in the binding of IL-6 in vivo.

Modulation of IL- 6 but not TNF $\alpha$ sequestration by suramin in vivo. It has recently been shown that IL-6 in the serum is complexed with several other proteins that can camouflage its immunoreactivity and bioactivity (34). Because the interpretation of the findings that suramin increased IL-6 levels in vivo is difficult, we attempted to determine whether suramin would

Table II. Improvement of Cachectic Parameters in Suramin-treated C-26-bearing Mice

\begin{tabular}{|c|c|c|c|c|c|c|c|c|c|c|c|c|}
\hline \multirow[b]{2}{*}{$\begin{array}{c}\text { Tumor bearing } \\
\text { treatment } \\
\text { mice/group } \\
\text { parameter }\end{array}$} & \multicolumn{3}{|c|}{ Exp. 1} & \multicolumn{5}{|c|}{ Exp. 2} & \multicolumn{4}{|c|}{ Exp. 3} \\
\hline & $\begin{array}{c}+ \\
\text { PBS } \\
5\end{array}$ & $\underset{6}{\stackrel{+}{\text { Suramin }}}$ & & $\begin{array}{c}+ \\
\text { PBS } \\
6\end{array}$ & $\underset{6}{\stackrel{+}{\text { Suramin }}(1)}$ & $\underset{6}{+} \stackrel{+}{\text { Suramin }}(2)$ & $\begin{array}{c}- \\
\text { PBS } \\
5\end{array}$ & & $\begin{array}{c}+ \\
\text { PBS } \\
6\end{array}$ & $\underset{6}{\stackrel{+}{\text { Suramin }}}$ & $\begin{array}{c}- \\
\text { PBS } \\
6\end{array}$ & \\
\hline Initial wt. (g) & $29.3 \pm 1.8$ & $27.5 \pm 0.8$ & NS* & $26.1 \pm 0.4$ & $26.4 \pm 0.4$ & $26.1 \pm 0.3$ & $26.8 \pm 0.6$ & $\mathrm{NS}^{*}$ & $25.6 \pm 1.1$ & $26.1 \pm 1$ & $26.1 \pm 0.5$ & $\mathrm{NS}^{*}$ \\
\hline Final wt. (g) & $21.7 \pm 0.7$ & $25.9 \pm 0.8$ & 0.0001 & $21.3 \pm 0.8$ & $24.5 \pm 0.7$ & $25.1 \pm 1.2$ & $28.7 \pm 0.9$ & 0.0001 & $20.9 \pm 2.4$ & $24.9 \pm 1.7$ & $27.1 \pm 0.5$ & 0.008 \\
\hline Tumor wt. (g) & $1.65 \pm 0.13$ & $1.82 \pm 0.49$ & NS & $1.46 \pm 0.12$ & $1.5 \pm 0.1$ & $1.9 \pm 0.4$ & & & $1.1 \pm 0.1$ & $1.2 \pm 0.1$ & & NS \\
\hline Host's wt. (g) & $20.2 \pm 0.8$ & $24.2 \pm 1.1$ & 0.0001 & $19.6 \pm 0.8$ & $23.0 \pm 0.6$ & $23.1 \pm 1.2$ & $28.7 \pm 0.9$ & 0.004 & $19.8 \pm 2.5$ & $23.7 \pm 1.6$ & $27.1 \pm 0.5$ & 0.008 \\
\hline Dry wt. (g) & $5.8 \pm 0.4$ & $6.9 \pm 0.5$ & 0.02 & $5.9 \pm 0.2$ & $7.1 \pm 0.3$ & $7.0 \pm 0.4$ & $8.8 \pm 0.2$ & 0.001 & $6.7 \pm 1.1$ & $8.7 \pm 1.2$ & $10.6 \pm 0.7$ & 0.05 \\
\hline Epididymal fat (mg) & $35 \pm 30$ & $118 \pm 61$ & 0.02 & $30 \pm 6$ & $94 \pm 36$ & $95 \pm 30$ & $268 \pm 40$ & 0.01 & $97 \pm 56$ & $197 \pm 43$ & $329 \pm 24$ & 0.006 \\
\hline Heart wt. (mg) & NT & NT & NT & $102 \pm 7$ & $119 \pm 5$ & $118 \pm 11$ & $136 \pm 7$ & 0.01 & NT & NT & NT & NT \\
\hline Serum IL-6 (U/ml) & $158 \pm 32$ & $384 \pm 99$ & 0.02 & $138 \pm 41$ & $290 \pm 146$ & $412 \pm 256$ & $6 \pm 2$ & 0.02 & $115 \pm 28$ & $176 \pm 26$ & $7 \pm 3$ & 0.02 \\
\hline Serum glucose (mg/dl) & $44 \pm 21$ & $113 \pm 9$ & 0.001 & NT & NT & NT & NT & NT & $40 \pm 18$ & $78 \pm 26$ & $188 \pm 18$ & 0.02 \\
\hline
\end{tabular}

$\mathrm{CDF}_{1}$ male mice were inoculated with C-26.IVX cells on day 0 . In exp. 1 , mice received PBS $(0.5 \mathrm{ml})$ or suramin $(200 \mathrm{mg} / \mathrm{kg}$ i.p.) on days 7 and 13 , and the experiment was terminated on day 17. In exp. 2, the grop designated suramin (1) received a total of $6 \mathrm{mg} / \mathrm{mouse}$, divided over $5 \mathrm{~d}(1.2 \mathrm{mg} / \mathrm{d})$ between days 7 and 11 . The group designated suramin (2) received two injections of suramin on days 7 and $11(3 \mathrm{mg} /$ injection per mouse) and were killed on day 17 . In exp. 3, mice received an identical treatment to that in exp. 2, suramin (1), and were killed on day 15 . Results are expressed as mean $\pm \mathrm{SD}$. NT, not tested. ${ }^{*} P$ values represents the difference between suramin-treated and PBS-treated C-26-bearing mice. 


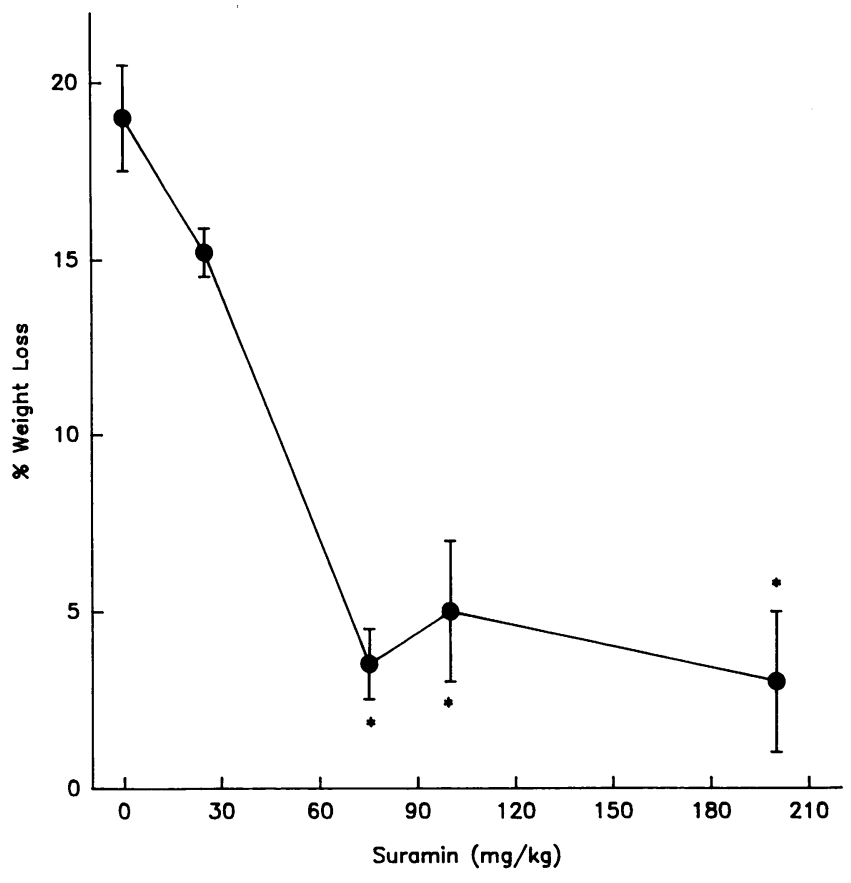

Figure 5. Dose-dependent inhibition of wasting by suramin. Increasing amounts of suramin were injected on days 7 and 12 after tumor inoculation. Shown is percent weight loss on day 17. There were five to six mice per group. ${ }^{*} P<0.002$.

interfere with IL-6 binding in vivo. Table III illustrates the ability of suramin to significantly reduce the sequestration of ${ }^{125}$ I-IL-6 to the livers of normal $\mathrm{CDF}_{1}$ mice. In contrast, suramin increased the radioactivity associated with the kidney ( Table III), but did not change the level of radioactivity in the blood (not shown). Under the same conditions in a subsequent experiment, suramin inhibited ${ }^{125}$ I-IL- 6 binding to the liver by $48 \%$ and significantly increased radioactivity present in the urine $(111,833 \pm 3,590 \mathrm{cpm}$ in $0.1 \mathrm{ml}$ urine from suramin-injected mice vs. $45,251 \pm 10,568 \mathrm{cpm}$ in $0.1 \mathrm{ml}$ urine from PBSinjected mice, measured $1 \mathrm{~h}$ after radioactive IL-6 injection). This increase in urine radioactivity suggests that suramin may accelerate the clearance of IL- 6 in vivo. Of note, the administration of $15 \mu \mathrm{g}$ of unlabeled IL-6, together with $1.2 \mathrm{ng}$ of ${ }^{125} \mathrm{I}-\mathrm{IL}-6$, failed to reduce the liver-associated radioactivity (not shown). Therefore, the background binding of ${ }^{125} \mathrm{I}-\mathrm{IL}-6$ in the assay shown in Table III is unknown.

Suramin was $\sim 10$-fold less potent in inhibiting receptor binding of TNF $\alpha$ than IL-6 to indicator cells in culture (Fig.
Table IV. Suramin Does Not Inhibit TNF $\alpha$ Uptake by the Liver

\begin{tabular}{|c|c|c|c|c|}
\hline & \multicolumn{2}{|c|}{$\begin{array}{c}\mathrm{TNF} \alpha \\
(2.8 \mathrm{ng} / \text { mouse }) \\
\end{array}$} & \multicolumn{2}{|c|}{$\begin{array}{c}\text { IL-6 } \\
(2.4 \mathrm{ng} / \text { mouse }) \\
\end{array}$} \\
\hline & PBS & Suramin & PBS & Suramin \\
\hline & \multicolumn{4}{|c|}{$c p m \pm S D$} \\
\hline Liver & $52,684 \pm 3,439$ & $55,339 \pm 9,091$ & $42,295 \pm 2,068$ & $22,378 \pm 2,801$ \\
\hline Kidney & $10,151 \pm 1,443$ & $13,774 \pm 1,365$ & $21,319 \pm 796$ & $51,123 \pm 6,840$ \\
\hline Spleen & $3,236 \pm 158$ & $3,011 \pm 475$ & $1,625 \pm 371$ & $1,684 \pm 270$ \\
\hline
\end{tabular}

The experiment was performed and the results are expressed as indicated in Table III. There were three mice per group. Mice were killed $30 \mathrm{~min}$ after intravenous administration of radioactive cytokine.

1). Therefore, it was of interest to determine whether suramin would inhibit TNF $\alpha$ uptake by the liver in vivo. Table IV clearly demonstrates that whereas suramin inhibited liver-associated IL-6 radioactivity, the drug failed to decrease liver-associated TNF radioactivity.

Lack of additivity between suramin and anti-IL-6 antibody in vivo. Previous results demonstrated the ability of the rat anti-murine IL-6 mAb 20F3 to inhibit C-26-mediated cachexia (11). The administration of this antibody and of suramin significantly inhibited $(P<0.01$ from control-treated mice) C-26-mediated wasting (Fig. 6). However, the coadministration of both the 20F3 antibody and suramin did not add to the protection against wasting provided by suramin alone. One possible interpretation for this lack of additivity is that suramin inhibits wasting by interfering with the action of IL- 6 in vivo.

\section{Discussion}

Previous observations in myeloma cells that suramin inhibits IL-6-stimulated growth and immunoglobulin secretion (17, 18 ) suggested that suramin could also interfere with experimental cancer cachexia where IL-6 was shown to be involved (11). We demonstrate here for the first time the capacity of a chemical (i.e., suramin ) to interfere with the binding of IL-6 to its cell surface receptor and to have a significant beneficial effect on reducing cancer-associated weight loss.

In a dose-dependent fashion, suramin inhibits the proliferation of B-9 cells (a standard IL-6 bioassay) in response to IL-6. The ability of the drug to inhibit IL-6-dependent growth is not restricted to this cytokine, since suramin inhibits the proliferation of the same indicator cells to IL-4 (Table I). The findings

Table III. Suramine Modulates ${ }^{125}$ I-IL-6 Sequestration In Vivo

\begin{tabular}{|c|c|c|c|c|c|c|}
\hline & \multicolumn{2}{|c|}{$30 \mathrm{~min}$} & \multicolumn{2}{|c|}{$60 \mathrm{~min}$} & \multicolumn{2}{|c|}{$120 \mathrm{~min}$} \\
\hline & PBS & Suramin & PBS & Suramin & PBS & Suramin \\
\hline & \multicolumn{6}{|c|}{$c p m \pm S D$} \\
\hline Liver & $15,792 \pm 963(5.3)$ & $8,831 \pm 1,361(2.9)$ & $8,244 \pm 467(2.9)$ & $4,893 \pm 781(1.6)$ & $7,135 \pm 110(2.4)$ & $4,030 \pm 441(1.3)$ \\
\hline Kidney & $19,618 \pm 580(6.5)$ & $63,719 \pm 7,783(21.2)$ & $8,772 \pm 1,455(2.9)$ & $37,432 \pm 1,773(12.4)$ & $2,565 \pm 218(0.8)$ & $17,031 \pm 1,506(5.7)$ \\
\hline
\end{tabular}

Normal CDF 1 mice were injected intravenously with PBS $(0.2 \mathrm{ml})$ or with suramin $(5 \mathrm{mg}), 20$ min before intravenous administrations of ${ }^{125} \mathrm{I}-\mathrm{IL}-6$ $(300,000 \mathrm{cpm} ; \sim 1.2 \mathrm{ng})$. At the indicated time points (relative to the injection of ${ }^{125}$-IL-6), mice were killed and organs were removed and counted. Results are expressed as $\mathrm{cpm} \pm \mathrm{SD}$ of four mice. Liver radioactivity is expressed as $\mathrm{cpm} / \mathrm{g}$ tissue. The numbers in parentheses indicate percent of injected cpm. 


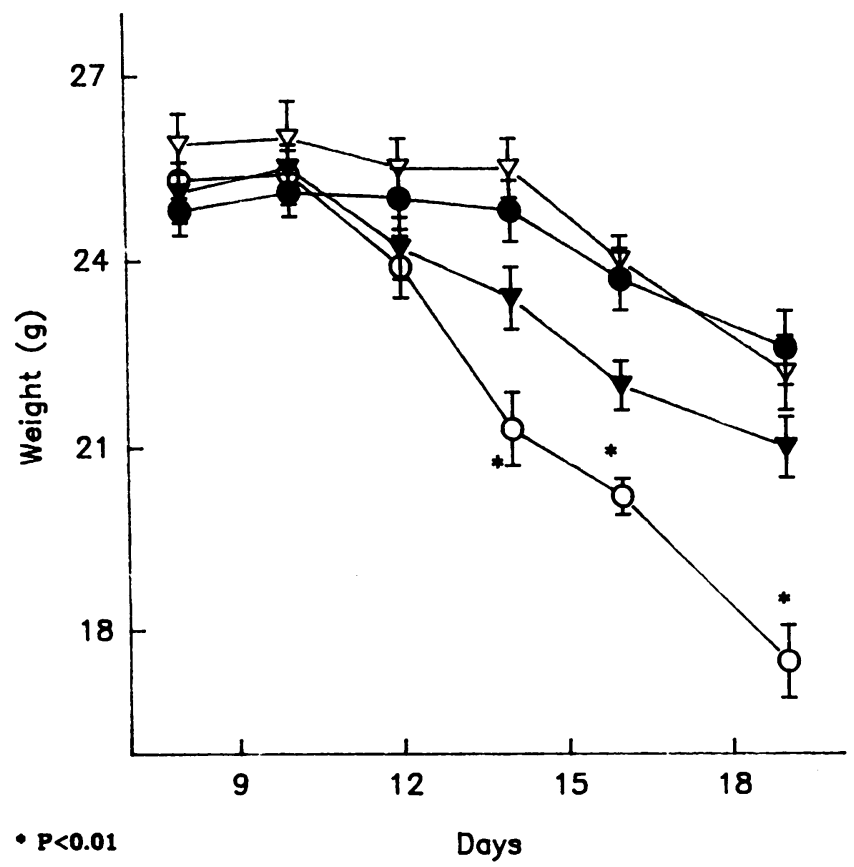

Figure 6. Anti IL-6 treatment does not influence suramin inhibition of weight loss. Mice were inoculated with $5 \times 10^{5} \mathrm{C}-26$ IVX cells on day 0 . On days 6 and 11 , one group of mice was injected intraperitoneally with PBS (open circles). Other groups received the $20 \mathrm{~F} 3 \mathrm{mAb}$ ( $1 \mathrm{mg}$; filled triangles) or suramin ( $2 \mathrm{mg}$; open triangles). The group represented by the filled circles received the same amount of both suramin and of the $20 \mathrm{~F} 3 \mathrm{mAb}$ on the same days. There were five mice per group.

that the extent of inhibition had an inverse relation to the amount of IL-6 and, second, that the inhibitory effect of the compound could be removed in pretreatment experiments (up to $1 \mathrm{mM}$, for $1 \mathrm{~h}$; data not shown), suggest that the effect of suramin on B-9 cells is reversible. Radioreceptor assays conducted at $4^{\circ} \mathrm{C}$ showed that suramin inhibited the binding of radioactive IL-6 to U-266 human myeloma in a dose-dependent manner (Fig. 1). It is interesting to note that suramin was found to be 10 -fold less potent in inhibiting the binding of TNF $\alpha$ to the MCF-7 human breast cancer line. More direct evidence for the interference of IL-6 receptor binding by suramin comes from crosslinking studies. As previously reported, crosslinking membrane-bound ${ }^{125}$ I-IL-6 to U-266 cells generates three IL-6-containing crosslinked complexes with molecular masses of 100,120 , and $150 \mathrm{kD}$ (35). The 100- and 120-kD complexes represent one and two molecules, respectively, of IL-6(20 kD) crosslinked to an $80-\mathrm{kD}$ membrane protein, whereas the $150-\mathrm{kD}$ complex consists of IL-6 crosslinked to a $130-\mathrm{kD}$ membrane protein. These molecular masses exactly correspond with those of two membrane glycoproteins, gp80 and gp 130, that participate in the IL-6 receptor system (36). It is possible that suramin exerts its effect by interfering with the initial interaction of IL- 6 with the gp 80 receptor molecule. The compound was unable to dissociate IL- 6 once bound by the receptor complex, as shown by crosslinking experiments (Fig. 3 ) and radioreceptor assays (data not shown), suggesting that suramin directly interacts with and blocks binding site domains rather than altering the conformation of the ligand or receptor molecules. Whether suramin binds directly to IL-6, to the receptor subunits, or indirectly to a cell surface component in close proximity to the receptor remains to be established. However, under the conditions used here $\left(4^{\circ} \mathrm{C}\right)$, suramin does not appear to act by inducing IL- 6 receptor internalization or shedding. It also is possible that suramin exerts its inhibitory action by binding directly to the IL- 6 molecule. However, this offers only a partial explanation, since the stoichiometry between IL-6 and suramin requires a vast excess of the drug. Previous studies have shown that suramin inhibits the binding of a variety of other growth factors to their corresponding cell surface receptors (25-29). These results, together with our data, do not support a specific antagonistic role for suramin in preventing/interfering with the binding of IL-6. This differs, for example, from the case of IL-1 receptor antagonist, where the inhibition of binding is highly specific to IL-1 proteins (37). Alternatively, since suramin is a heavily negatively charged molecule, its mechanism of action may involve indiscriminate binding to positively charged regions within the ligand binding site of many receptor types. These possibilities are currently under investigation.

Coincident with the inhibitory action of suramin on IL-6 binding to indicator cells in culture, suramin exhibits a positive effect on cachexia in vivo. The administration of the drug to C-26-bearing hosts reduced the deleterious effects of the tumor in a time- and dose-dependent manner (Figs. 4 and 5). Specifically, two administrations of suramin at doses of $\geq 75 \mathrm{mg} / \mathrm{kg}$ prevented, by $\sim 60 \%$, the loss of precachectic weight of C-26bearing hosts. Body compositional analysis revealed that suramin inhibited the wasting of both muscle and fat tissues, and reduced the extent of hypoglycemia (Table II). Because suramin did not prevent C-26-mediated weight loss completely, it is possible that IL- 6 is but one of several factors influencing host catabolism in the C-26 cachexia model. These still undetermined factors might be suramin insensitive. One such suramin-insensitive factor may be the competition between progressing C-26 tumors and the host for essential nutrients, a phenomenon known to occur in experimental cachexia (38). The beneficial effect of suramin on weight loss is not due to added nutritional value, since the drug is known to be poorly metabolized (22).

Suramin treatment did not result in a decrease of tumor burden at the same time as it protected weight loss. This suggests that the drug affects the host directly. In some experiments, a small but significant augmentation of tumor size was seen in suramin-treated mice. However, this phenomenon occurred at a time when suramin-treated mice were protected from weight loss, while control-treated animals exhibited significant wasting. In addition, when a given dose of the drug was administered over a 5-d period, rather than injected twice, the increase in tumor burden disappeared (Table II). Moreover, suramin neither inhibited nor augmented the growth of C-26.IVX (data not shown), in contrast to its ability to prevent the proliferation of several other cancer lines in culture (14, 15). Taken together, this information establishes a role for suramin as an anticachectic agent, in addition to its known antineoplastic effect. It remains to be established whether suramin prevents wasting associated with the growth of other tumors in vivo.

Suramin inhibits IL-6 activities in vitro and suppresses catabolism of C-26-bearing mice, where IL-6 plays a role in mediating cachexia (11), in vivo. An attempt, therefore, was 
made to link these two observations. Experiments with trace amount of radioactive IL-6 showed that suramin modulated the sequestration of the cytokine in vivo. Whereas the drug significantly lowered (up to 50\%) the radioactivity associated with the liver, it elevated the radioactivity present in the kidney (Table III) and in the urine (now shown). Similar to the situation with suramin, the administration of a $\mathrm{mAb}$ against murine IL-6 receptor significantly lowered (50\%) the amount of radioactivity associated with the liver and increased the radioactivity associated with the kidney (not shown). Further experimentation is required to establish the effect of the drug on specific binding of this cytokine to the liver. Interestingly, suramin did not influence the uptake of radioactive TNF $\alpha$ by the liver (Table IV). While these results do not support a specific antagonistic role of suramin in preventing IL- 6 binding, the data demonstrate that the drug exhibits a certain level of selectivity in its action in vivo. The collective implication of the findings presented here support the hypothesis that suramin inhibits C-26mediated cachexia, in part, by preventing the binding of IL- 6 to its receptor in vivo. Further support for this hypothesis may be found in the experiment where anti-IL-6 mAb treatment did not increase the protection against cachexia provided by suramin administration in vivo (Fig. 6). In addition to IL-6, suramin also prevents the binding of IL-1 to type I and II IL-1 receptors (G. Strassmann, unpublished results). IL-1 has been shown to upregulate IL- 6 production by the C-26 tumor in vitro (12), and intratumoral, but not systemic, administration of IL-1 receptor antagonist inhibits C-26-mediated wasting (39). Since suramin treatment increases IL-6 levels in the circulation of C-26-bearing mice, it is not likely that inhibition of cachexia in vivo is due to tumor IL-1 receptor blockade. It is still possible, however, that suramin inhibits the action of other factors that, together with IL-6, may influence C-26-mediated cachexia.

IL-6 is a multifunctional cytokine. In addition to its involvement in cancer cachexia, it has been implicated in the pathophysiology of rheumatoid arthritis, Kaposi sarcoma, B cell malignancies, Castleman's disease, cardiac myxoma (39), and Alzheimer syndrome (40). Ultimately, then, the identification of suramin as an inhibitor of IL-6 may lead to the discovery of other chemicals capable of exerting even more potent and specific antagonism to this pleiotropic cytokine.

\section{Acknowledgment}

We thank Dr. J. J. Oppenheim for reviewing the paper, and Mr. Mike Platt for administrative support.

\section{References}

1. Tracey, K. J., and A. Cerami. 1992. Tumor necrosis factor in the malnutrition (cachexia) of infection and cancer. Am. J. Trop. Med. Hyg. 47:2-7.

2. Langstein, H. N., and J. A. Norton. 1991. Mechanism of cancer cachexia. Hematol.-Oncol. Clin. N. Am. 5:103-123.

3. Tisdale, M. J. 1991. Cancer cachexia. Br. J. Cancer. 63:337-342.

4. Warren, S. 1932. The immediate causes of death in cancer. Am. J. Med. Sci. 184:610-615.

5. Van Eys, J. 1982. Effect of nutritional status of response to therapy. Cancer Res. 42(Supp.):747-753.

6. DeWys, W. D., C. Begg, P. T. Lavin, P. R. Band, J. M. Bennet, J. R. Bertino, M. H. Cohen, H. O. Douglass, P. F. Engstrom, E. Z. Ezdimli, et al. 1980 Prognostic effect of weight loss prior to chemotherapy in cancer patients. Am.J. Med. 69:491-497.
7. Chlebowski, R. T. 1985. Critical evaluation of the role of nutritional support with chemotherapy. Cancer (Phila.) 55:268-272.

8. Beutler, B., J. Mahoney, N. Letrang, P. Pekala, and A. Cerami. 1985. Purification of cachectin, a lipoprotein lipase-suppressing hormone from endotoxin induced RAW-2647 cells. J. Exp. Med. 161:984-994.

9. Tracey, K. J., H. Wei, K. R. Manogue, Y. Fon, D. G. Hesse, H. T. Nguyen, G. C. Kuo, B. Beutler, R. S. Cotran, A. Cerami, and S. F. Lowry. 1988. Cachectin/tumor necrosis factor induces cachexia anemia and inflammation. $J$. Exp. Med. 167:1211-1231.

10. Vlassara, H., R. J. Spiegel, D. S. Doval, and A. Cerami. 1986. Reduced plasma lipoprotein lipase activity in patients with malignancy associated weight loss. Horm. Metab. Res. 18:698-703.

11. Strassmann, G., M. Fong, J. S. Kenney, and C. O. Jacob. 1992. Evidence for the involvement of interleukin-6 in experimental cancer cachexia. J. Clin. Invest. 89:1681-1684.

12. Strassmann, C. O., Jacob, R. Evans, D. Beall, and M. Fong. 1992. Mechanisms of experimental cancer cachexia. Interaction between mononuclear phagocytes and colon 26 carcinoma and its relevance to IL-6 mediated cancer cachexia. J. Immunol. 148:3674-3678.

13. Hawkins, F. 1940. Concentration of Bayer-205 (Germanin) in human blood and cerebrospinal fluid after treatment. Trans. R. Soc. Trop. Med. Hyg. 34:87-91.

14. Taylor, C. W., R. Lui, P. Fanta, and S. F. Salmon. 1992. Effects of suramin on in vitro growth of fresh human tumors. J. Natl. Cancer Inst. 84:489-494.

15. Vignon, F., C. Prebois, and H. Rochefort. 1992. Inhibition of breast cancer growth by suramin. J. Natl. Cancer Inst. 84:38-42.

16. De Clercq, E. 1979. Suramin: a potent inhibitor of reverse transcriptase of RNA tumor viruses. Cancer Lett. 8:9-22.

17. Freter, C. E. 1989. Synergistic growth inhibition of lymphoid tumor cells by dexamethasone and suramin. Proc. Am. Assoc. Cancer Res. 30:545. (Abstr.)

18. Shiao, R., A. Solfson, and C. E. Freter. 1991. Glucorticoid and suramin inhibition of IL-6 stimulated immunoglobulin secretion. Proc. Am. Assoc Cancer Res. 32:325. (Abstr.)

19. Fantini, J., J. B. Rognani, M. Rosehabianca, G. Pommier, and J. Marvaldi. 1989. Suramin inhibits cell growth and glycolytic activity and triggers differentiation of the human coli adenocarcinoma cell clone 4T29-D4. J. Biol. Chem. 264:10282-10286.

20. Nakajima, M. A. Dechavingy, C. E. Johnson, J. Hamada, C. A. Stein, and G. L. Nicolson. 1991. Suramin, a potent inhibitor of melanoma heparinase and invasion. J. Biol. Chem. 266:9661-9666.

21. Bojanowski, K., S. Lelievre, J. Markovita, J. Couprie, A. J. Sablon, and A. K. Larsen. 1992. Suramin is an inhibitor of DNA topoisomerase II in vitro and in Chinese hamster fibrosarcoma cells. Proc. Natl. Acad. Sci. USA. 89:30253029.

22. Broder, S., J. M. Collins, P. D. Markham, R. R. Redfield, D. F. North, J. F. Groognan, R. C. Gallo, R. Yarchoan, H. C. Lane, R. W. Kloecker, H. Mitsuya, E. Gelmann, L. Resnick, C. E. Myers, and A. S. Fauci. 1985. Effects of suramin on HTLV-III/LAV infection presenting as Kaposi's sarcoma or AIDS related complex: clinical pharmacology and suppression of virus replication in vivo. Lancet. ii:627-630.

23. Stein, C. A., R. V. LaRocca, R. Thomas, N. Achtee, and C. E. Myers. 1989. Suramin: an anti cancer drug with a unique mechanism of action. J. Clin. Oncol. 7:499-508.

24. Zaniboni, A. 1990. Suramin: the discovery of an old anticancer drug. Med. Oncol. Tumor Pharmacother. 7:287-290.

25. Williams, L. T., P. H. Trumble, M. F. Lavin, and E. Sunday. 1984. Platelet derived growth factor receptors from a high affinity state in membrane preparations, kinetics and affinity cross linking studies. J. Biol. Chem. 259:5287-5294.

26. Coffey, R. J., E. B. Leof, G. D. Shipley, and H. L. Moses. 1987. Suramin inhibition of growth factor receptor binding and mutagenicity in AXR-2B cells. J. Cell. Physiol. 132:143-148.

27. Pollak, M., and M. Richard. 1990. Suramin blockade of insulin like growth factor I stimulated proliferation of human osteosarcoma cells. $J$. Natl. Cancer Inst. 82:1349-162.

28. Betsholtz, C., A. Johnson, C. H. Heldin, and B. Westermark. 1986. Efficient reversion of simian sarcoma virus transformation and inhibition of growth factor induced mutagenesis by suramin. Proc. Natl. Acad. Sci. USA. 83:64406444.

29. Huang, J. S., S. S. Huang, and M. D. Kuo. 1986. Bovine brain derived growth factor and purification and characterization of its interaction with responsive cells. J. Biol. Chem. 261:11600-11607.

30. Dower, S. K., S. R. Kronheim, C. J. March, P. J. Conlon, T. P. Hopp, S. Gillis, and D. L. Urdal. 1985. Detection and characterization of high affinity plasma membrane receptors for human interleukin 1. J. Exp. Med. 162:501-515.

31. Sharon, M., R. D. Klausner, B. R. Cullen, R. Chizzonite, and W. J. Leonard. 1986. Novel interleukin-2 receptor subunit detected by cross-linking under high-affinity conditions. Science (Wash. DC). 234:859-863.

32. Strassmann, G., D. R. Bertolini, S. B. Kerby, and M. Fong. 1991. Regulation of murine mononuclear phagocyte inflammatory products by macrophage 
colony stimulating factor: lack of IL-1 and prostaglandin $\mathrm{E}_{2}$ production and generation of a specific IL-1 inhibitor. J. Immunol. 147:1279-1285.

33. Tanaka, Y., H. Eda, T. Tanaka, T. Udagawa, T. Ishikawa, and T. Taguchi. 1990. Experimental cancer cachexia induced by transplantable colon 26 adenocarcinoma in mice. Cancer Res. 50:2290-2295.

34. May, L. T., N. H. Viguet, J. S. Kenney, N. Ida, A. C. Allison, and P. B. Sehgal. 1992. High levels of complexed interleukin-6 in human blood. J. Biol. Chem. 267:19698-19704.

35. D'Allesandro, F., O. R. Colamonici, and R. P. Nordan. 1993. Direct association of IL-6 with a $130 \mathrm{kDa}$ component of the IL-6 receptor system. $J$. Biol. Chem. 268:2149-2153.

36. Hibi, M. M., Murakami, M. Saito, T. Hirano, T. Taga, and T. Kishimoto 1990. Molecular cloning and expression of an IL-6 signal transducer, gp 130. Cell. 63:1149-1157.
37. Dinarello, C. A., and R. C. Thompson. 1991. Blocking IL-1: interleukin 1 receptor antagonist in vivo and in vitro. Immunol. Today. 12:404-410.

38. Garattini, S., A. Bizzi, M. G. Donelli, A. Guaitani, R. Samanin, and F. Spreafico. 1980. Anorexia and cancer in animals and man. Cancer Treat. Rev. 7:115-139.

39. Strassmann, G., Y. Masui, R. Chizzonite, and M. Fong. 1993. Mechanisms of experimental cancer cachexia. Local involvement of IL-1 in colon-26 tumor. J. Immunol. 150:2341-2345.

40. Hirano, T., S. Akira, J. Taga, and T. Kishimoto. 1990. Biological and clinical aspects of interleukin 6. Immunol. Today. 11:443-449.

41. Strauss, S., J. Bauer, U. Ganter, U. Jonas, M. Berger, and B. Volk. 1992. Detection of interleukin 6 and alpha 2 macroglobulin immunoreactivity in cortex and hippocampus of Alzheimer's disease patients. Lab. Invest. 66:223-230. 